\title{
MINIMUM-COST NUMERICAL PREDICTION SYSTEM FOR WIND POWER IN URUGUAY, WITH AN ASSESSMENT OF THE DIURNAL AND SEASÖNAL CYCLES OF ITS QUALITY.
}

\author{
${ }^{1}$ Gabriel Cazes Boezio e ${ }^{2}$ Sofia Ortelli \\ ${ }^{1}$ Universidad de la República, Uruguai \\ ${ }^{2}$ Usinas y Trasmisiones Eléctricas, Uruguai
}

\section{RESUMO}

Este trabalho apresenta os resultados de um sistema de previsão numérica de custo mínimo para a energia elétrica gerada pelos parques eólicos operacionais no Uruguai. Ao manter em níveis mínimos, tanto os custos computacionais como a complexidade das correções empíricas dos resultados numéricos, obtemos uma referência para a habilidade de previsão de sistemas de previsão mais complexos, que é facilmente disponivel durante os estágios de calibração e funcionamento operacional. O trabalho também visa explorar o ciclo diurno e sazonal da qualidade das previsões. Verifica-se que esse sistema de previsão simples produz resultados muito bons, embora as dependências da habilidade e erros de previsão em relação à estação do ano e à época de o dia é distinguível. Verifica-se também que é necessário levar em consideração os ciclos diurnos e sazonais durante a calibração das correções empíricas. Os bons resultados desta técnica simples poderiam ter sido possíveis devido à topografia relativamente suave do Uruguai.

Palavras-chave: Previsão numérica. Ciclo diario. Ciclo anual

\section{Abstract}

This work presents the results of a numerical forecast system of minimum cost for the electric power generated by wind farms in Uruguay. By keeping at minimum levels both the computational costs and the complexity of the empirical corrections of the numerical results, we obtain a benchmark for the forecast skill of more complex forecast systems, that is easily available during their calibration stages and operative functioning.

The work also aims to explore the diurnal and seasonal cycle of the forecasts quality. It is found that this simple forecast system produces very good results, albeit the dependencies of the forecast skill and errors respect to the season of the year and the time of the day are distinguishable. It is also found that it is necessary to take into account the diurnal and the seasonal cycles during the calibration of the empirical corrections. The good results of this simple technique might had been possible due to the relative smooth topography of Uruguay.

Keywords: NWP. diurnal cycle. seasonal cycle 


\section{Introduction}

Numerical predictions of wind near the earth surface beat the persistence forecast after the third hour, and the combination of both systems of prediction is useful only up to the sixth hour (Mello, Boezio e Gutierrez (2015)). After this period, numerical predictions are the best method to predict wind near surface or wind power generated by wind farms. Systematic and accidental errors can be associated to the large scale simulation (Bhargava, Kalnay e Carton (2017)) or to the simulation of local processes, such of those of the atmospheric boundary layer (Frediani et al. (2016), GarcíaDiez et al. (2013), Seidel, Chi e Li (2010)). In this work we present a forecast system of electric wind power generated in Uruguay. The forecast system is designed with maximum simplicity. It includes an empirical correction of the numerical outputs, which aims to correct the systematic errors of the forecasts, and acknowledges explicitly the diurnal and seasonal cycles.

\section{Field data, numerical simulations and electric power forecasts}

Usinas y Trasmisiones del Estado (UTE), the national electricity utility of Uruguay, provided hour means of electric power generated by nine wind farms of Uruguay. UTE also provided simultaneous data of wind measurements and availability of aero generators within each park. The quality of these data was checked by analyzing, for each hour, the consistency of these three variables (generated power, measured wind and availability of aero generators), as described by Ortelli and Boezio (2017).

The numerical simulations were obtained with the WRF model. The simulations are initiated at 0:00GMT of each day, extend for 96 hours and get their initial and boundary conditions from the GFS of NOAA. The regional simulations consider a single domain, with an horizontal resolution $30 \mathrm{~km}$. In the vertical direction, the resolution is relative high, consisting in 54 levels, $7 \mathrm{of}$ each within the first $100 \mathrm{~m}$ above the Earth's surface. Figure 1 shows the horizontal grid used by the regional model and the location of the wind farms considered.

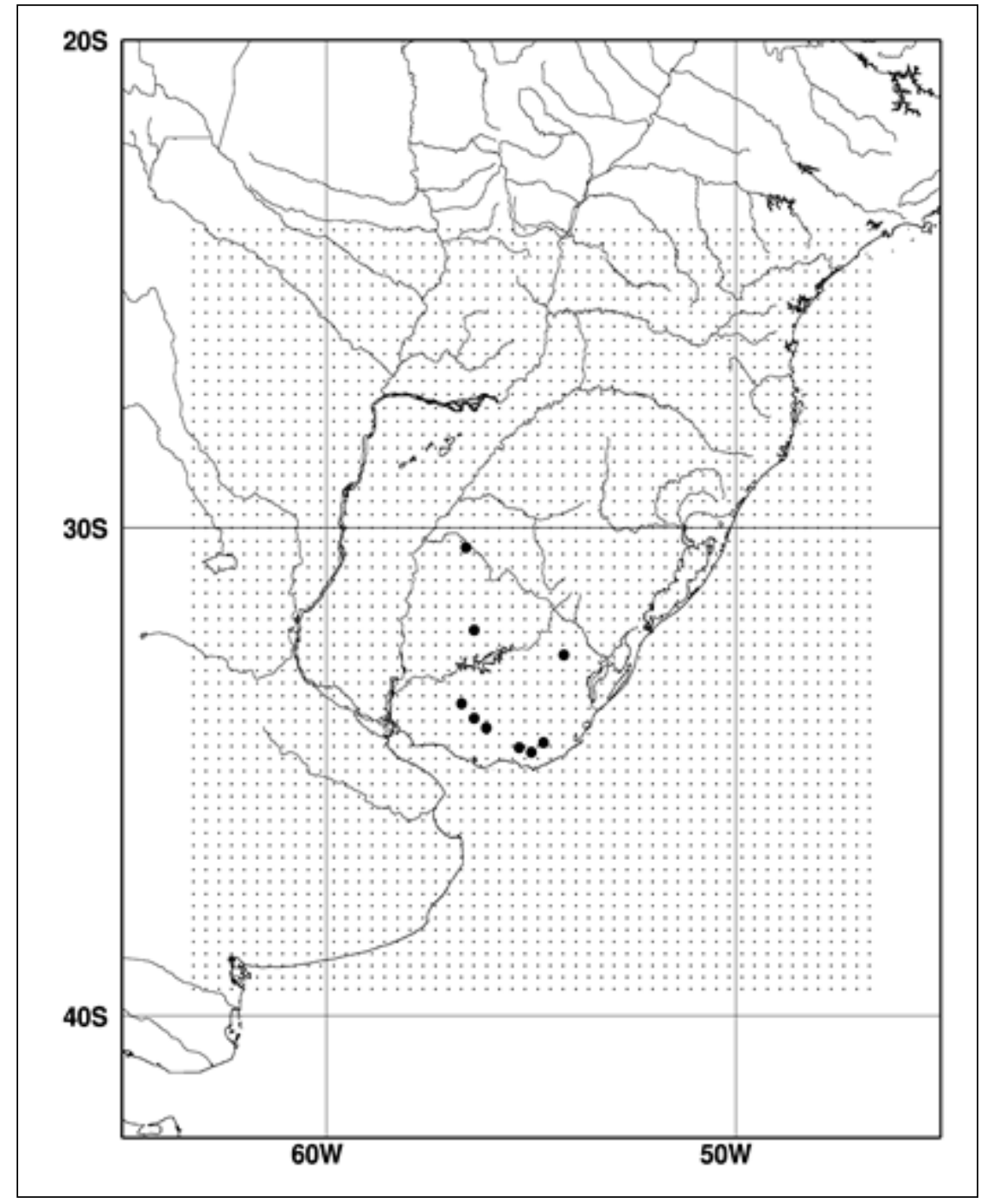

Figure 1 - Horizontal grid of the regional model (thin points) and wind farms considered (thick points). 


\subsection{Electric power forecasts}

Fist, a wind forecast is obtained for each wind farm. To do so, the hourly wind fields forecasted by the WRF model are interpolated to a single point in the horizontal domain, and to a vertical level, that are representative of the location of the wind farm and the height of its wind turbines. The resulting wind is multiplied by an empirical speed up factor, and the electric power is deduced using the wind speed-power curve of the generators installed in the wind farm. We compute one speed up factor for each wind farm, for each hour within the forecasted period, and for each one of two seasons: one from May 2016 to October 2016 (winter season) and the other from November 2015 to April 2016 (summer season). Each empirical speed up factor is computed to minimize the absolute difference of the seasonal means of observed and forecasted electric power for each hour within the forecast horizon, in order to correct the systematic forecast errors.

\subsection{Cross validation procedure}

The speed up factors of each wind farm are computed following a cross validation procedure. For each of the two seasons considered, we take away from the forecasts sample the forecast that corresponds to a particular day of initialization, say day number " $\mathrm{N}$ ". We also take away the two previous ( $\mathrm{N}-1$ and $\mathrm{N}-2)$ and the two following days $(\mathrm{N}+1$ and $\mathrm{N}+2)$. With the remaining sample, a speed up coefficient is chosen for each hour of the forecast horizon. Then, the resulting speed up coefficients are applied to the forecast initialized at day N. This is done for all the forecasts within the season, so the data of each forecast is not considered in its empirical correction (neither the data of the adjacent ones, that may not be completely independent of it).

\section{Results}

We asses the quality of the forecasts for the total power generated by all the wind farms considered. Figure 2 shows histograms of errors (forecasted minus recorded power) for the first 24 hours of "useful forecasts", for the winter (a) and summer (b) seasons. This 24 hours period period starts at the ninth hour of the forecast horizon, since at this time it is safe to count with the availability of the GFS products and the results of the regional simulations that use them. It is found that the histograms are quite symmetric, implying that the procedure of empirical correction of systematic errors is effective. Note that the cross validation procedure prevents the artificial correction that may occur for any particular sample, if the same data used to calibrate are used to validate. summer season.

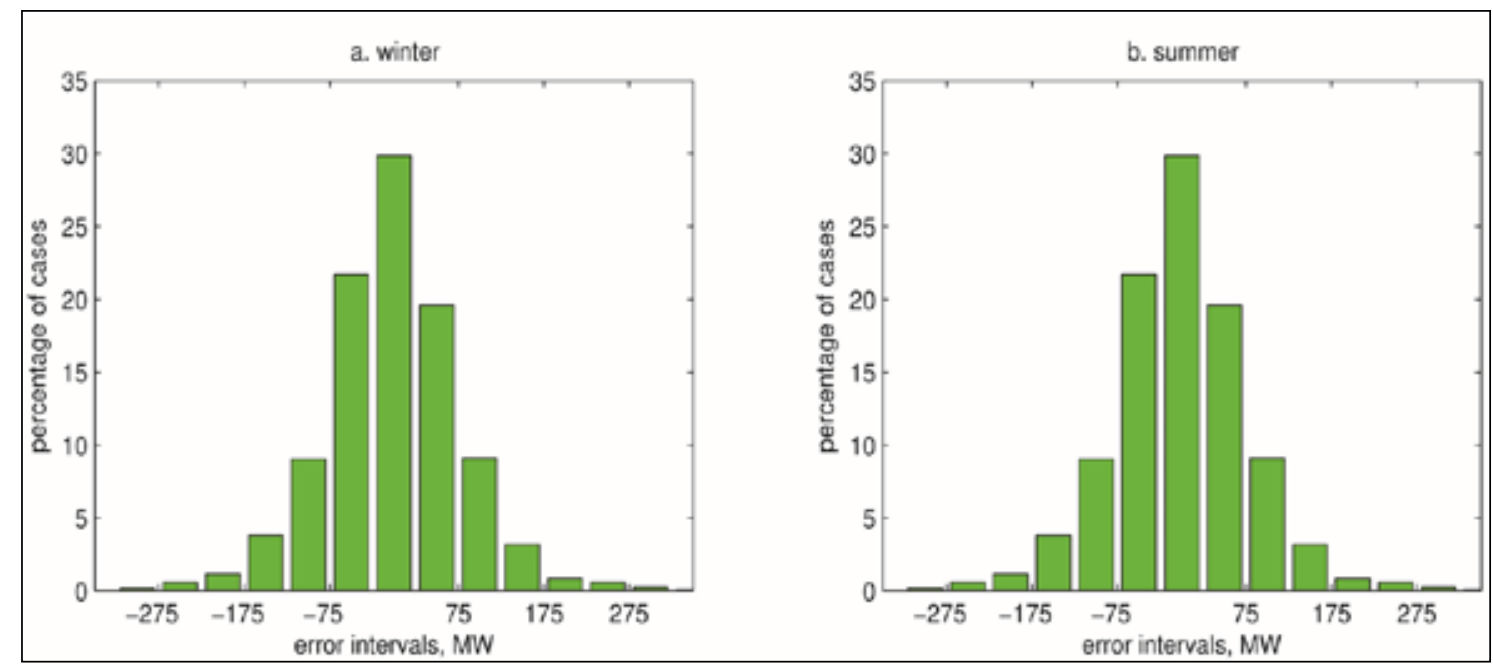

Figure 2 - Histograms of forecast errors (forecasted minus observed power). a, winter season, b, summer season

Figure 3 shows the forecasts skill and the mae divided by the total installed capacity of the wind farms (relative mae or Rmae) for winter (blue line) and summer (red line). The skill of winter forecasts appears to be better than the skill of summer ones during most of the time horizon considered. Rmae is better for winter forecasts during the whole forecast horizon. The figure indicates the ninth forecasted hour with a black vertical line. The skill is found to be between 0.9 ans 0.8 during the first 24 hours of useful forecasts in winter, and between 0.8 to 0.7 in summer. Rmae is found to be around 0.10 the first 24 hours of useful forecasts in winter, and around 0.12 in summer. The skill and Rmae show a diurnal cycle during winter, which is not clear during summer. The decay of the forecast quality 
during the time horizon is more pronounced during summer. Note that this decay is modulated by a diurnal cycle during winter; actually winter forecast during day time are better than those of the immediate night time that follows.

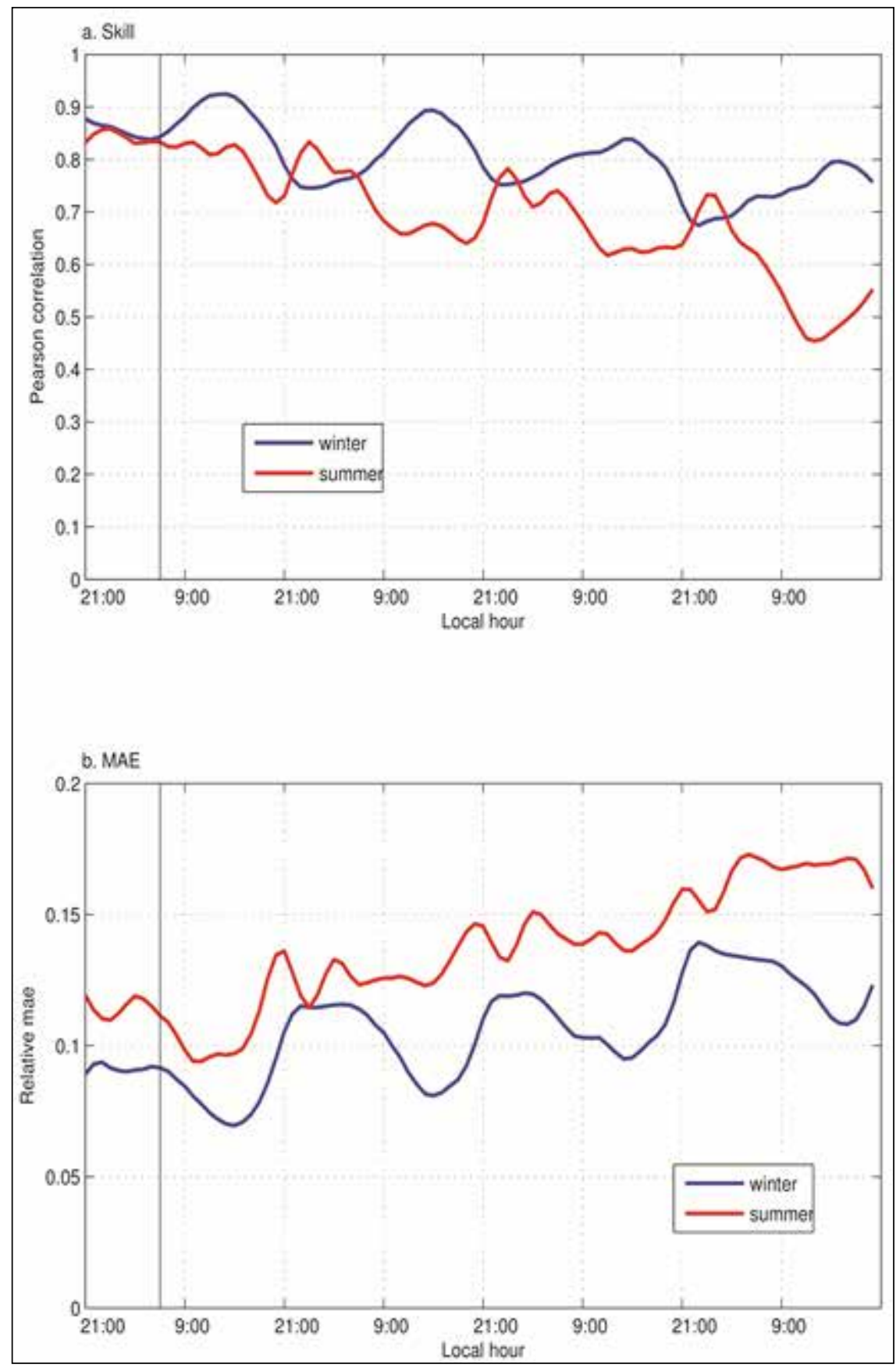

Figura 3 - a: Skill as Pearson correlation during the forecast horizon. Blue line, winter season, red line, summer season. b: same as a, for relative mae.

Figure 4 shows the speed ups coefficients obtained for three of the nine wind farms considered (at this point we don't specify which are, considering confidentiality issues). It is found that the speed up coefficients have distinguishable diurnal and seasonal cycles, indicating that this is also the case with the systematic errors of the combined numerical models. How each one of the two models involved (GFS and WRF) contributes to the systematic errors is open to study. 


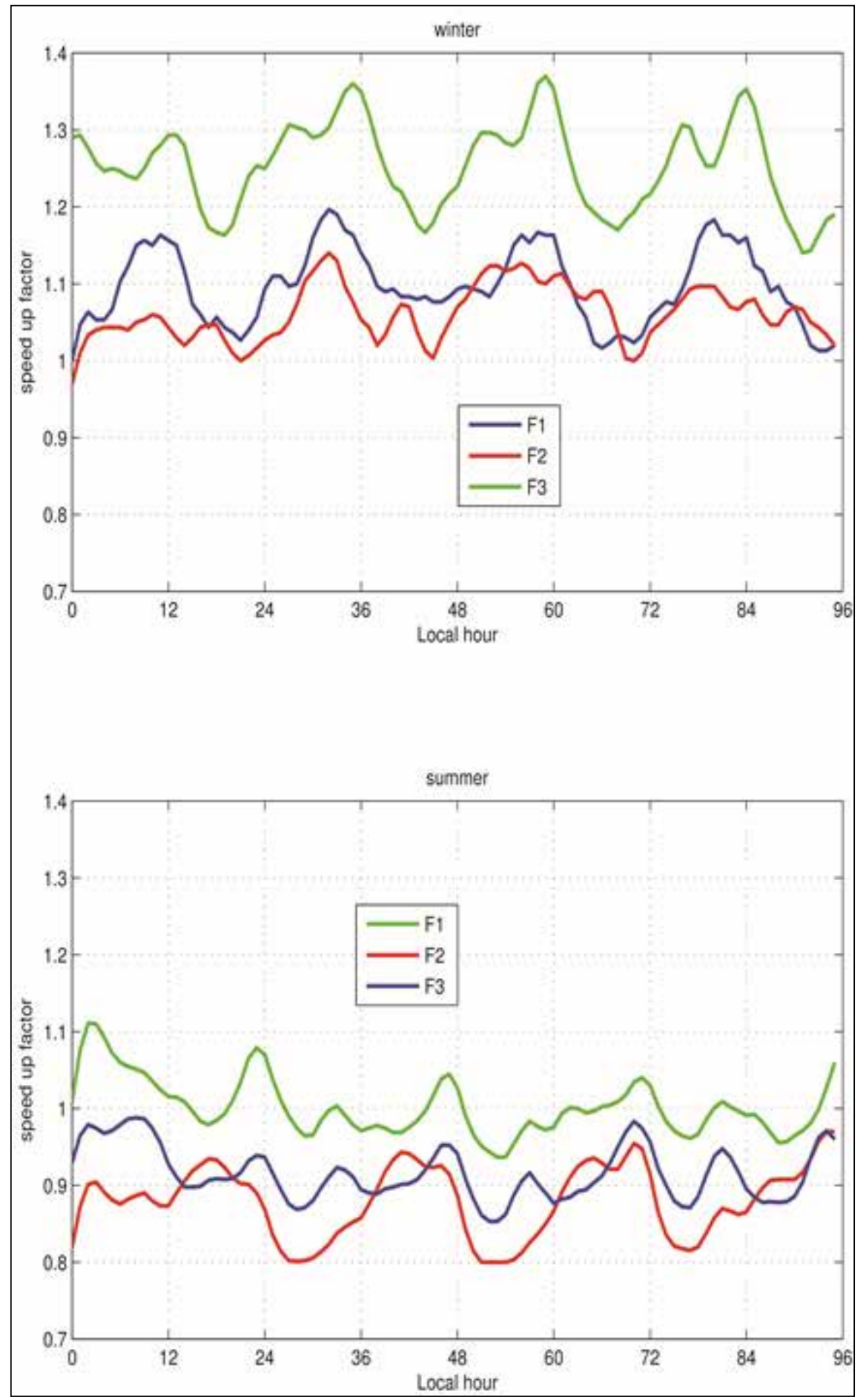

Figure 4 - Speed up coefficients, as function of time within the forecast horizon, for three selected wind farms. a, winter season. b, summer season.

\section{Summary and discussion}

The simple forecast system presented in this work shows encouraging results, that pose a challenge of quality to more complex forecast systems. Forecast quality, in terms of Pearson correlation and Rmae shows a seasonal cycle (the winter forecasts are better). During winter, a diurnal cycle is also noticeable, being day time forecasts better than night time ones. The speed up coefficients, which were calibrated to correct systematic errors, also have diurnal and seasonal cycles. This indicates that the systematic errors of the GFS-WRF combination used here also have these cycles. It is open to study if the simulation of large 
scale circulation, which may imply errors in the GFS, or the simulation of local processes, such as vertical static stability at the atmospheric boundary layer, which would be more related to the regional simulation, need to be improved.

The fact that good results were obtained with low resolution simulations may be related with the relatively smooth orography of the region of interest.

\section{Acknowledgment}

This work was supported by Usinas y Trasmisiones Eléctricas de Uruguay (UTE), through the contract UTE-Universidad de la República, “Forecast System for Electric Wind Power in Uruguay.” Ing Marcos Riberiro, Ing. Pablo Vogel and Ing. Andrés Tozzo of UTE helped with many aspects of this work while contributing to the referred contract.

\section{References}

BHARGAVA; KALNAY, E.; CARTON, J. A. Estimation and correction of the gfs systematic errors. In: AMERICAN METEOROLOGICAL SOCIETY MEETING, 97., 2017, Keystone. Anais eletrôni cos... Boston: American Meteorological Society, 2017. Availavable at: <https:/ams.confex.com/ams/97Annual/webprogram/ Paper305798.html>.

FREDIANI, M.; HACKER, J. P.; ANANGNOSTOU, E. N.; HOPSON, T. Evaluation of pbl parameterizations for modeling surface wind speed during storms in the northeast united states. weather and forecasting. Weather and Forecasting, v. 31, p. 1511-1528, 2016.

GARCíADIEZ, M.; FERNáNDEZ, J.; FITA, L.; YAGüE, C. Seasonal dependence of wrf model biases and sensitivity to pbl schemes over europe. Quarterly Journal of the Royal Meteorological Society, v. 139, p. 501-514, 2013.

DE MELLO, S..; BOEZIO, G. C.; GUTIERREZ, A. Operational wind energy forecast with power assimilation. In: INTERNATIONAL CONFERENCE ON WIND ENERGY, 14., 2015. Porto Alegre, RS, 2015.

ORTELLI, S.; BOEZIO, G. C. Construction of empirical speed-power curves in wind farms installed in uruguay. application to real-time data quality control and estimation of possible generation in case of restriction. In: $X$ WORKSHOP BRASILEIRO DE MICROMETEOROLOGIA, 10., 2017. Santa Maria, RS, 2017. Available at: <https:// www.fing.edu.uy/cluster/eolica/publi/ICWE14_02237.pdf>.

SEIDEL, D. J.; CHI, O. A.; LI, K. Estimating climatological planetary boundary layer heights from radiosonde observations: Comparison of methods and uncertainty analysis. J. of Geophysical Research, v. 115, p. D16113, 2010.

Gabriel Cazes Boezio

Universidad de la República, Uruguai E-mail: agcm@fing.edu.uy

\section{Sofia Ortelli}

